\title{
Short Term Load Forecasting for Turkey Energy Distribution System with Artificial Neural Networks
}

\author{
Salih TOSUN, Ali ÖZTÜRK, Fatih TAŞPINAR
}

\begin{abstract}
The constant increase in consumption of electricity has become one of the biggest problems today. The evaluation of energy resources has also made it worthwhile to consume it. In this respect, the transmission of electric energy and the operation of power systems have become important issues. As a result, reliable, high quality and affordable energy supply has become the most important task of operators. Realizing these elements can certainly be accomplished with good planning. One of the most important elements of this planning is undoubtedly consumption estimates. Therefore, knowing when consumers will consume energy is of great importance for operators as well as energy producers. Consumption estimates or, in other words, load estimates are also important in terms of the price balance that will occur in the market. In this study, the short-term load estimation of Düzce, Turkey is performed with Artificial Neural Networks (ANN). In the study, the April values were taken as reference and the estimates were obtained according to the input results of this month. As a result of this study, it is seen that the load consumption with nonlinear data can be successfully forecasted by ANN.
\end{abstract}

Keywords: Artificial Neural Networks (ANN); Electric Energy; Short-Term Load Forecasting

\section{INTRODUCTION}

One of the most important problems in planning and operating the power system for the future is estimating the electrical load. In addition, load estimation and planning are closely related to the reliability of power systems. Accurately estimated loads are required in the electricity price estimation. If the production and consumption is not balanced, the imbalance cost occurs. The most important factor in reducing the imbalance costs is the consistency of the load estimates. The problem is not only valid for system operators but also for market operators and for transmission network owners or market operators [1-2]. There are a variety of socio-political and environmental factors that influence the load estimate. In addition, there are nonlinear and random behaviours of loads in the system. Due to these factors, the issue becomes a difficult subject to understand and deal with [1-3]. It cannot be foreseen what kind of load, when, and how to switch in power systems. Also, situations such as unexpected failures in the system complicate the situation.

An attempt is made to estimate the hourly or daily load with the short-term load estimate. According to these estimations, load sharing between power plants and the times when the power plants enter and leave the circuit are determined [4]. Load estimates may be short-term as well as long-term estimates [5]. When the literature is searched, various methods of estimating the load have been developed. A similar-day approach is a prediction method based on modelling by similar historical data from the past, covering the data from two or three years before [6]. One of the most-common methods used is the curve fitting approach. These methods make predictions by modelling the factors such as weather, day type and consumer profile. Time series approach, as applied in the problems from social area to economics, from statistics to many technical field, also load estimation by time series methods are very common. Artificial Neural Networks and Fuzzy Logic methods are also seen as one of the methods used in load estimation. Due to the developments in computer technology, load prediction systems have begun to use expert-systems that have been used frequently in recent years $[6,10]$.

In many studies of ANN based electric load forecasting, short-term values of temperature have been used and hourly load, peak load, daily load and total load have been predicted [11]. On the other hand, hourly values of System Marginal Price, System Potential Demand and System Power Reserve have been involved in one step ahead forecasting of System Marginal Price using ANN [12]. In the prediction of electric load, short-term historical data was used as the input of ANN models. Lee et al. predicted the short-term load for a large power system by applying ANN method that was inputted from weekday and weekend day data [13]. Meteorological data patterns were also successfully exploited in short-term load forecasting studies. The ANN models in 1 to 10 days shortterm load forecasting have been used constructed based on variations in meteorological patterns [14].

Several studies have been carried out in the developed countries of the world on load profiles and load estimations. A work done in the UK, a home's daily electricity consumption profile has been revealed [15]. In a study on load profiles, the customers were classified and load profiles were obtained for homes that consume $40 \%$ of the total electricity in Norway [16]. In these two studies, it is assumed that all the houses have the same characteristics. In another study, it was tried to estimate the energy consumption of housing by ANN method [17]. One of the other important and first studies was the estimation of the short-term twenty-four hour load using expert systems [18]. However, in this study all days are considered to be the same type. Another issue of the study is to estimate the load by determining the profiles of the customers as well as the load estimate [19]. In a different study, electricity consumption predictions for commercial buildings were made [20].

In the formation of the energy market place in Turkey, the estimations that are based on solely the energy consumption data from the prior year without taking the meteorological data into account have been used. In this study, daily atmospheric temperature values were used to estimate the load by considering the seasonal changes. The 
short-term electricity load estimation for Düzce is performed with ANN models. Here, the values obtained for April were taken as reference and the estimates were obtained according to the input results of this month. The day type, hour of the day, hourly air temperature from actual and prior days and hourly consumption data synchronized to the other inputs were defined as the input variables to the ANN models. The values obtained by the prediction method were compared with the realized values and performance analysis was performed.

\section{ARTIFICIAL NEURAL NETWORKS}

ANN is an information processing system that is inspired by human biological nerve networks and contains some features similar to human neural networks [21]. ANNs have powerful methods in non-linear forecasting studies through their learning ability on partially interrupted and lower accuracy data. One of their important abilities is to enable us to retrain them on an untrained dataset to simulate the latest situations without making big modifications. Therefore, they can work fast in the application as the calculations have been synchronized internally. On the other hand, they have some disadvantages such as to construct new models for every different problem with a desired accuracy. So, ANN models can yield inconvenient and unacceptable results depending on the training method and data used. Moreover, ANN models could not be constructed for some problems due to accuracy issues. The ANN model produces connection weights between the elements of it, which cannot be interpreted clearly, so, the predictions with ANN models return a black-box model [22].

With the ANN which imitates the human brain in a simple way, learning, optimization, analysis, classification, generalization can be applied successfully [23]. One of the important areas where ANN is used is forward-looking estimates. The smallest units that constitute the work of ANN are called artificial nerve cells. As shown in Fig. 1, an artificial neural cell consists of five layers.

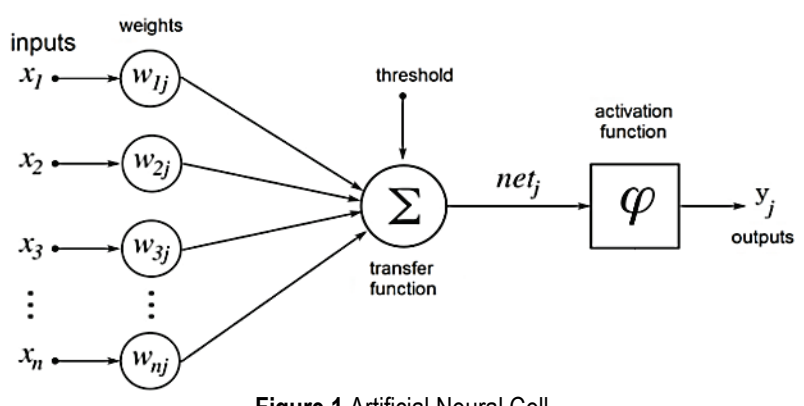

Figure 1 Artificial Neural Cell

If these layers are examined, input is from outside or from other cells into the artificial neural cell. Weights, information arriving at the artificial nerve cell are multiplied by a weighting factor and transmitted to the kernel before reaching the kernel. Thus the effect of the input can be increased or decreased. Inputs, which are multiplied by weights, are collected by the summation function. The summation function is as given in Eq. (1) [24].

$$
N e t=\sum_{j=1}^{n} x_{j} * w_{j}+b
$$

Here, Net is the sum of the resultant multiplication of the variables entering the ANN, $x$ are the variables entering the algorithm, $w$ is the weights that affect the variables, and $b$ is the threshold value. The activation function is the output produced by computing the net information coming to the cell, calculated against this input. The non-linear function is usually chosen as the activation function. The reason for this comes from the nonlinear property of ANN, which is easily necessary for derivation [25]. With the activation function, the information from the sum is converted into output. The match between the activation function and the input and output information is provided. The correct selection of the activation function will affect the performance of the network [26]. There are various activation functions, but in this work the sigmoid function given in Eq. (2) is chosen as the activation function. In equality, $y$ means output [27].

$y=\frac{1}{1-e^{-N e t}}$

An important part of ANN is structures of the network. Networks can have several features, and there can be more than one layer between the input and output layers. Intermediate layers are also expressed as hidden layers. It is easier to calculate complex operations with these layers [28]. ANN mainly operates in two stages of training and testing. Outputs are calculated according to the weight of the training stage. With the test phase, the system is tested with the data that ANN does not have knowledge. In this study, learning is provided by using various ANN learning algorithms. These are Levenberg Marquardt (LM), Levenberg Marquardt (BR) and Levenberg Marquardt (SCG) learning algorithms. The LM algorithm is preferred due to the speed and stability that are provided in the training of ANN [29]. The BR algorithm is based on the premise of automatically setting the best possible performance, achieving excellent generalization [30]. The SCG algorithm is typically used where the convergence rates are low and the parameters must be described by the user. Generally, the performance of the algorithm gives good results [31].

The error values are calculated as a result of the output values obtained by learning algorithms. The function for which the error function is minimized is given in Eq. (3).

$E=\frac{1}{2} \sum_{k=1}^{n}\left(y_{k}-t_{k}\right)^{2}$

In equality, $E$ is the error function, $y_{k}$ is the output produced by the network, and $t_{k}$ is the real value. Data entering ANN must be subjected to certain operations before input. This process is expressed as normalization and the value is shifted between 0 and 1 . This speeds up the process. In this study, the min-max normalization given in Eq. (4) is used [31].

$$
x^{\prime}=\frac{x_{i}-x_{\min }}{x_{\max }-x_{\min }}
$$


In this study, various criteria are used to measure the predictive accuracy. The Mean Squared Error (MSE) method was widespread used to measure the consistency of the ANN forecast results. $R^{2}$ is used as another criterion. $R$ shows the correlation between the actual value and the estimated value. Generally, the estimation power shows the relationship between the forecast and the actual value, especially expressed as $R^{2}$ and ranges in $0-1$. As $R^{2}$ value approaches to 1, the estimation is strong. Eq. (5) and Eq. (6) give $M S E$ and $R^{2}$ equations, respectively.

$$
\begin{aligned}
& M S E=\frac{1}{n} \sum[E(t)]^{2} \\
& R^{2}=\frac{\sum_{i=1}^{n}\left(y_{i}-\bar{y}\right)^{2}-\sum_{i=1}^{n} E_{i}^{2}}{\sum_{i=1}^{n}\left(y_{i}-\bar{y}\right)^{2}}
\end{aligned}
$$

where $E$ is the error value, $n$ is the number of data, $\bar{y}$ is the average of all $y$ values, $y_{i}$ is the $i$ value.

\section{APPLICATION}

This study was carried out based on the Automatic Meter Reading System (AMRS) in the Western Black Sea Region (SEDAŞ) and the counters read in residential and commercial areas. As shown in Fig. 2, remote meter reading of electricity consumption was carried out in SEDAS distribution areas covering the cities Kocaeli, Sakarya, Düzce and Bolu. With this system, the electricity meters can be read remotely via wireless (GPRS) access and the data can be collected at a central location.

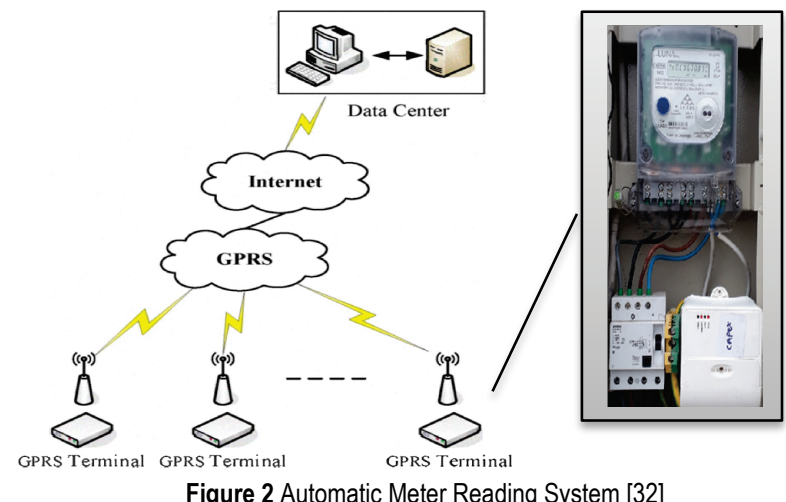

According to the study, sample residential and commercial subscriptions were determined according to the criteria in Tab. 1 and meters readable on hourly basis were connected. Numbers of meters are determined by taking the constraints such as urban population, settlement type, meter type used and monthly energy consumption amounts as the table shows. As shown in Tab. 1, the consumption amount is collected in three groups. Monthly Consumers up to $150 \mathrm{kWh}$ were taken as low group and coded with 150 numbers. Consumers whose monthly consumption is between $151-250 \mathrm{kWh}$ are defined as those in the normal group and are coded with a number of 250 . Consumers whose monthly consumption exceeds $250 \mathrm{kWh}$ are defined as high group and are coded with number 251.The remote data read within the scope of AMRS was subjected to a review in April. The consumption values recorded were all hourly based with a sampling rate of 24 in a day for training and testing data sets.

Table 1 Creation of groups according to monthly consumption

\begin{tabular}{|c|c|c|c|}
\hline $\begin{array}{c}\text { Consumption } \\
\text { Group }\end{array}$ & $\begin{array}{c}\text { Daytime } \\
\text { Consumption }\end{array}$ & $\begin{array}{c}\text { Peak } \\
\text { Consumption }\end{array}$ & $\begin{array}{c}\text { Night } \\
\text { Consumption }\end{array}$ \\
\hline $0-150$ & Low & Low & Low \\
\hline $151-250$ & Normal & Normal & Normal \\
\hline 251 and over & High & High & High \\
\hline
\end{tabular}

All the used ANN models in this study were threelayered error back-propagation type ANNs with feedforwarded inputs. In the training phase, ANN models were organized in different network structures. Hence, ANN structures with the neuron counts in input, hidden and output layers such as 4-10-1, 4-20-1, 4-30-1 and 4-40-1 are used and tested. In order to identify the best ANN model several training optimization algorithms such as LM, BR and SCG have been applied to the same dataset. At the same time, the performances of network structures for this specific problem were also tested. The network structure and one of the ANN structures designed in the form of 410-1 are shown in Fig. 3.

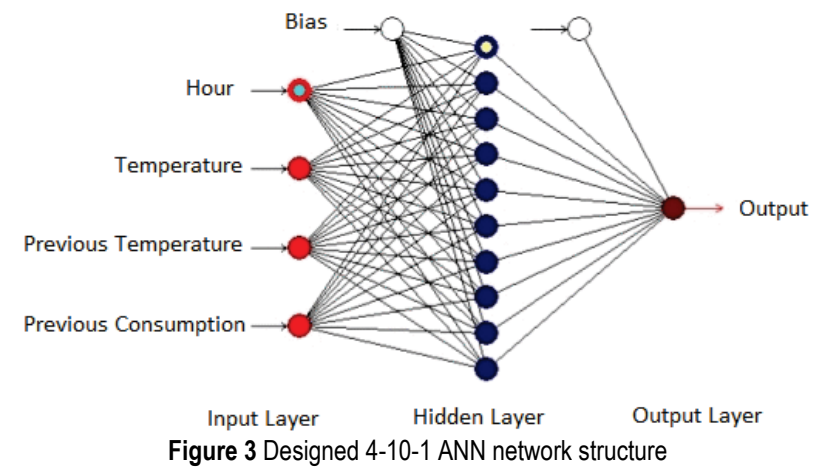

In this network structure, information coming from the outside enters the algorithm through the input layer. They are transmitted to the output layer by the effect of their weight on the intermediate layer or hidden layers. The relationship between this input and output provides network learning.

In the training phase, an early stopping criterion has been applied. The learning rate (LR) has been found iteratively within a loop by reducing a starting $L R$ value of 0.01 by 0.01 at every epoch till the early stopping criteria were valid. Early stopping criteria are determined according to MSE value in training whether to continue learning of ANN. If an MSE value was not changed at $0.01 \%$ between two consequent epochs then early stopping was applied. The LR value at early stopping criteria was the final LR of the actual ANN in training. The inputs to the ANN models include the day time, hour of the day, hourly air temperature from actual and prior days and prior consumption data while the target or output variable is the actual hourly consumption. These values were entered as data to ANN after being subjected to normalization process. After the data has been trained, the test phase is passed. Because the days of the week are not considered similar, the training is conducted separately for each day of the week. In the selected algorithms, algorithms were run with $70 \%$ of the data being trained, $15 \%$ verifying and $15 \%$ 
being tested. All the recorded consumers with the extreme values have been used in ANN modelling stage without trimming because ANN models have higher success rates with complete set of data.

In Tab. 2, only April Mondays are given and the estimates obtained after being trained are given. For example, only the 2-20-1 network performance values of the LM, BR and SCG learning algorithms are given in the table. These training approaches are well-known in supervised training algorithms that are applied to many different problems. In the training, every algorithm has been five times applied to each of days of the dataset and then the best ANN structure and the algorithm used was obtained.

These values given in Tab. 2 were plotted in Fig. 4 showing the errors between the actual value and ANN result.

Table 2 Data set trained for April 2015 Monday (MWh)

\begin{tabular}{|c|c|c|c|c|c|c|}
\hline \multirow{2}{*}{ Date } & \multirow{2}{*}{ Hour } & \multirow{2}{*}{$\begin{array}{c}\text { Temperature } \\
{ }^{\circ} \mathrm{C}\end{array}$} & \multirow{2}{*}{ Consumed Energy } & \multicolumn{3}{|c|}{ ANN Results (4-20-1) } \\
\hline & & & & Levenberg-Marquard & Bayesian Regularization & Scaled Conjugate Gradient \\
\hline \multirow[t]{9}{*}{ 4 April } & 00 & 7 & 26,84 & 23,85592 & 25,68214 & 26,37192 \\
\hline & 01 & 5 & 18,71 & 22,38635 & 20,15665 & 21,86843 \\
\hline & 02 & 5 & 16,47 & 15,79616 & 14,3395 & 15,48204 \\
\hline & 03 & 4 & 11,39 & 11,03833 & 11,85754 & 13,69477 \\
\hline & 04 & 4 & 10,77 & 10,116 & 11,82266 & 12,51362 \\
\hline & 05 & 4 & 11,59 & 10,63152 & 11,07994 & 11,1584 \\
\hline & 06 & 3 & 12,39 & 11,67003 & 12,40551 & 12,35329 \\
\hline & 07 & 2 & 15,14 & 15,37291 & 17,73171 & 16,82146 \\
\hline & . & . & . & . & . & . \\
\hline \multirow[t]{9}{*}{11 April } & 08 & 11 & 27,06 & 22,5924 & 21,72466 & 23,85791 \\
\hline & 09 & 13 & 20,90 & 22,42848 & 24,35665 & 28,04272 \\
\hline & 10 & 11 & 25,72 & 25,85213 & 25,87095 & 25,86194 \\
\hline & 11 & 13 & 29,22 & 28,56681 & 27,25776 & 30,55889 \\
\hline & 12 & 15 & 33,38 & 32,83412 & 27,93366 & 31,44895 \\
\hline & 13 & 17 & 34,33 & 33,35618 & 27,74194 & 29,62727 \\
\hline & 14 & 16 & 31,73 & 32,05983 & 29,54555 & 32,17948 \\
\hline & 15 & 18 & 30,33 & 30,16972 & 29,21759 & 30,60748 \\
\hline & . & . & . & . & . & . \\
\hline \multirow[t]{8}{*}{18 April } & 16 & 29 & 30,05 & 29,68952 & 31,45081 & 29,31696 \\
\hline & 17 & 30 & 30,04 & 29,73656 & 32,56401 & 31,58996 \\
\hline & 18 & 30 & 33,35 & 32,7264 & 34,09014 & 34,08676 \\
\hline & 19 & 30 & 31,18 & 31,85615 & 33,8586 & 32,03073 \\
\hline & 20 & 28 & 35,52 & 35,16037 & 33,59218 & 33,83206 \\
\hline & 21 & 24 & 37,41 & 37,1187 & 33,22938 & 35,35437 \\
\hline & 22 & 22 & 38,79 & 39,29185 & 31,51675 & 33,69131 \\
\hline & 23 & 16 & 30,77 & 34,74365 & 31,75851 & 32,40727 \\
\hline
\end{tabular}
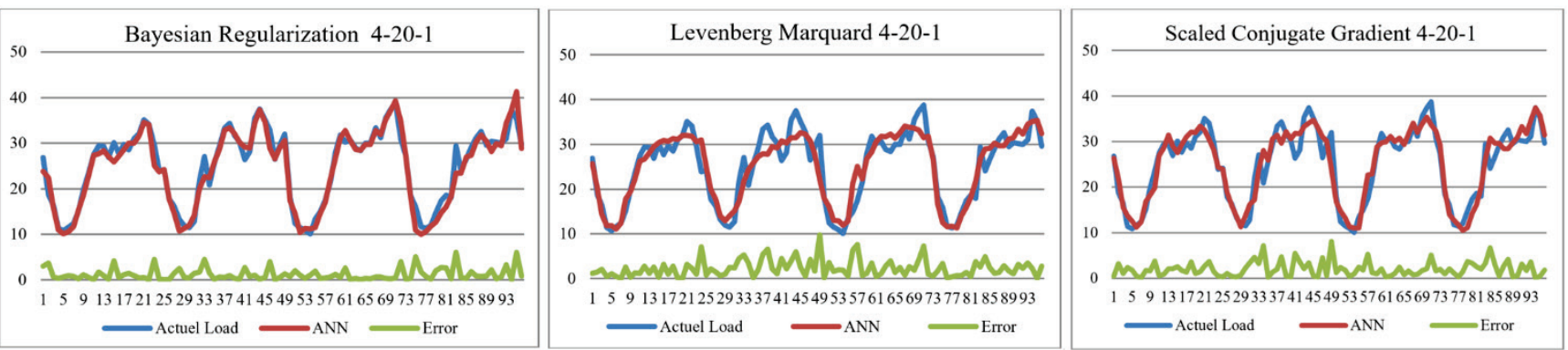

Figure 4 According to Learning Algorithms, in the 4-20-1 network structure, Actual, ANN Estimation and Error (only Monday)

Table 3 Table titles Comparative ANN learning algorithm and network structure results

\begin{tabular}{|c|c|c|c|c|c|c|c|c|}
\hline \multirow{2}{*}{ Day } & \multirow{2}{*}{ Training Algorithm } & \multirow{2}{*}{$\begin{array}{l}\text { Network } \\
\text { Structure }\end{array}$} & \multicolumn{2}{|c|}{ Training } & \multicolumn{2}{|c|}{ Testing } & \multicolumn{2}{|c|}{ Validating } \\
\hline & & & $M S E$ & $R$ & $M S E$ & $R$ & $M S E$ & $R$ \\
\hline \multirow{12}{*}{ Monday } & \multirow{4}{*}{ Levenberg-Marquardt } & $\begin{array}{lll}4 & 10 & 1 \\
\end{array}$ & 5,444 & 0,956 & 7,513 & 0,965 & 7,06 & 0,945 \\
\hline & & 4201 & 1,222 & 0,992 & 7,297 & 0,963 & 3,367 & 0,977 \\
\hline & & 4301 & 1,098 & 0,994 & 9,451 & 0,944 & 3,666 & 0,975 \\
\hline & & 4401 & 0,0161 & 0,999 & 10,38 & 0,924 & 2,977 & 0,977 \\
\hline & \multirow{4}{*}{$\begin{array}{c}\text { Bayesian } \\
\text { Regularization }\end{array}$} & $\begin{array}{lll}4 & 10 & 1\end{array}$ & 9,5 & 0,924 & 5,929 & 0,959 & 8,979 & 0,929 \\
\hline & & 4201 & 9,737 & 0,922 & 4,737 & 0,97 & 9,0 & 0,929 \\
\hline & & $430 \quad 1$ & 6,092 & 0,952 & 8,244 & 0,944 & 6,4 & 0,950 \\
\hline & & $\begin{array}{lll}4 & 40 & 1 \\
\end{array}$ & 9,016 & 0,93 & 8,887 & 0,917 & 8,997 & 0,929 \\
\hline & \multirow{4}{*}{$\begin{array}{l}\text { Scaled Conjugate } \\
\text { Gradient }\end{array}$} & $4 \quad 10 \quad 1$ & 7,514 & 0,933 & 14,738 & 0,938 & 9,529 & 0,925 \\
\hline & & 4201 & 6,415 & 0,95 & 5,017 & 0,968 & 6,644 & 0,949 \\
\hline & & $\begin{array}{lll}4 & 30 & 1 \\
\end{array}$ & 1,988 & 0,984 & 4,612 & 0,963 & 3,385 & 0,974 \\
\hline & & $\begin{array}{lll}4 & 40 & 1 \\
\end{array}$ & 1,905 & 0,998 & 8,633 & 0,93 & 5,581 & 0,960 \\
\hline
\end{tabular}


Graphical values for April, Monday are given as examples only in 4-20-1 network. Throughout the month of April, the values obtained in different learning algorithms and different network structures for each day of the week can be displayed on a table. In this case, it is possible to observe which network structure and which learning algorithm is successful. This situation is shown in Tab. 3 .

Table 3 Table titles Comparative ANN learning algorithm and network structure results (continuation)

\begin{tabular}{|c|c|c|c|c|c|c|c|c|}
\hline \multirow{2}{*}{ Day } & \multirow{2}{*}{ Training Algorithm } & \multirow{2}{*}{$\begin{array}{l}\text { Network } \\
\text { Structure }\end{array}$} & \multicolumn{2}{|c|}{ Training } & \multicolumn{2}{|c|}{ Testing } & \multicolumn{2}{|c|}{ Validating } \\
\hline & & & $M S E$ & $R$ & $M S E$ & $R$ & $M S E$ & $R$ \\
\hline \multirow{12}{*}{ Tuesday } & \multirow{4}{*}{ Levenberg-Marquardt } & $4 \quad 101$ & 8,088 & 0,942 & 6,683 & 0,961 & 7,971 & 0,950 \\
\hline & & 4201 & 1,684 & 0,989 & 11,71 & 0,966 & 5,357 & 0,966 \\
\hline & & 4301 & 2,103 & 0,986 & 10,13 & 0,965 & 5,31 & 0,967 \\
\hline & & $4 \quad 40 \quad 1$ & 1,41 & 0,993 & 19,318 & 0,931 & 5,27 & 0,967 \\
\hline & \multirow{4}{*}{$\begin{array}{c}\text { Bayesian } \\
\text { Regularization }\end{array}$} & $\begin{array}{lll}4 & 10 & 1 \\
\end{array}$ & 8,466 & 0,941 & 14,226 & 0,94 & 9,306 & 0,941 \\
\hline & & 4201 & 3,971 & 0,975 & 7,149 & 0,95 & 4.435 & 0,972 \\
\hline & & 4301 & 4,908 & 0,967 & 3,761 & 0,984 & 4,681 & 0,971 \\
\hline & & $\begin{array}{lll}4 & 40 & 1 \\
\end{array}$ & 6,728 & 0,959 & 3,869 & 0,969 & 6,31 & 0,960 \\
\hline & \multirow{4}{*}{$\begin{array}{l}\text { Scaled Conjugate } \\
\text { Gradient }\end{array}$} & $\begin{array}{lll}4 & 10 & 1 \\
\end{array}$ & 6,93 & 0,955 & 11,35 & 0,947 & 8,46 & 0,947 \\
\hline & & 4201 & 5,9 & 0,958 & 6,946 & 0,964 & 6 & 0,960 \\
\hline & & $\begin{array}{lll}4 & 30 & 1 \\
\end{array}$ & 5,83 & 0,961 & 4,557 & 0,977 & 6,545 & 0,958 \\
\hline & & $\begin{array}{lll}4 & 40 & 1 \\
\end{array}$ & 6,922 & 0,95 & 7,221 & 0,966 & 7,72 & 0,951 \\
\hline \multirow{12}{*}{ Wednesday } & \multirow{4}{*}{ Levenberg-Marquardt } & $\begin{array}{llll}4 & 10 & 1 \\
\end{array}$ & 4,341 & 0,971 & 5,23 & 0,962 & 5,754 & 0,958 \\
\hline & & $\begin{array}{lll}4 & 20 & 1 \\
\end{array}$ & 1,29 & 0,989 & 9,359 & 0,956 & 3,548 & 0,974 \\
\hline & & $\begin{array}{lll}4 & 30 & 1 \\
\end{array}$ & 3,343 & 0,975 & 13,03 & 0,945 & 6,578 & 0,959 \\
\hline & & $\begin{array}{lll}4 & 40 & 1 \\
\end{array}$ & 1,062 & 0,997 & 23,61 & 0,929 & 15,76 & 0,913 \\
\hline & \multirow{4}{*}{$\begin{array}{c}\text { Bayesian } \\
\text { Regularization }\end{array}$} & $\begin{array}{lll}4 & 10 & 1 \\
\end{array}$ & 7,9 & 0,944 & 7,468 & 0,933 & 7,844 & 0,942 \\
\hline & & $\begin{array}{lll}4 & 20 & 1 \\
\end{array}$ & 9 & 0,929 & 5,673 & 0,987 & 8,165 & 0,941 \\
\hline & & $\begin{array}{lll}4 & 30 & 1 \\
\end{array}$ & 9,079 & 0,93 & 2,474 & 0,989 & 8,116 & 0,941 \\
\hline & & $\begin{array}{lll}4 & 40 & 1 \\
\end{array}$ & 8,515 & 0,936 & 5,342 & 0,971 & 9,126 & 0,923 \\
\hline & \multirow{4}{*}{$\begin{array}{l}\text { Scaled Conjugate } \\
\text { Gradient }\end{array}$} & $\begin{array}{lll}4 & 10 & 1 \\
\end{array}$ & 9,44 & 0,93 & 8,7 & 0,92 & 10,35 & 0,924 \\
\hline & & $\begin{array}{lll}4 & 20 & 1 \\
\end{array}$ & 8 & 0,942 & 3,833 & 0,978 & 7,4 & 0,946 \\
\hline & & $\begin{array}{lll}4 & 30 & 1 \\
\end{array}$ & 7,646 & 0,95 & 11,08 & 0,979 & 7,845 & 0,944 \\
\hline & & $\begin{array}{lll}4 & 40 & 1 \\
\end{array}$ & 5,234 & 0,962 & 10,45 & 0,917 & 7,038 & 0,949 \\
\hline & & $\begin{array}{lll}4 & 10 & 1 \\
\end{array}$ & 6,537 & 0,953 & 8,333 & 0,95 & 8,1 & 0,949 \\
\hline & & $\begin{array}{lll}4 & 20 & 1 \\
\end{array}$ & 1,66 & 0,989 & 8,99 & 0,947 & 3,7 & 0,977 \\
\hline & Levenberg-Marquardt & $\begin{array}{lll}4 & 30 & 1 \\
\end{array}$ & 1,896 & 0,996 & 3,821 & 0,98 & 7,256 & 0,962 \\
\hline & & $\begin{array}{lll}4 & 40 & 1 \\
\end{array}$ & 2,79 & 0,999 & 6,646 & 0,967 & 5,42 & 0,965 \\
\hline & & $\begin{array}{lll}4 & 10 & 1 \\
\end{array}$ & 2,16 & 0,986 & 10,678 & 0,916 & 3,41 & 0,978 \\
\hline & Bayesian & 4201 & 4,472 & 0,971 & 8,681 & 0,95 & 5,08 & 0,967 \\
\hline Thursday & Regularization & $4 \quad 30 \quad 1$ & 5,107 & 0,968 & 3,979 & 0,965 & 4,942 & 0,968 \\
\hline & & $\begin{array}{lll}4 & 40 & 1 \\
\end{array}$ & 1,22 & 0,999 & 18,35 & 0,967 & 3,72 & 0,976 \\
\hline & & $\begin{array}{lll}4 & 10 & 1 \\
\end{array}$ & 10,05 & 0,926 & 7,4 & 0,968 & 9,139 & 0,940 \\
\hline & Scaled Conjugate & $\begin{array}{lll}420 & 1 \\
\end{array}$ & 9,452 & 0,939 & 8,764 & 0,953 & 8,412 & 0,950 \\
\hline & Gradient & $\begin{array}{lll}4 & 30 & 1 \\
\end{array}$ & 7,142 & 0,949 & 10,67 & 0,935 & 7,531 & 0,951 \\
\hline & & $\begin{array}{lll}4 & 40 & 1 \\
\end{array}$ & 5,988 & 0,957 & 6,095 & 0,975 & 7,51 & 0,950 \\
\hline & & $\begin{array}{lll}4 & 10 & 1 \\
\end{array}$ & 2,286 & 0,981 & 10,69 & 0,938 & 3,852 & 0,970 \\
\hline & Levenhero_Marouardt & $\begin{array}{lll}420 & 1 \\
\end{array}$ & 2,54 & 0,981 & 6,746 & 0,953 & 4,34 & 0,967 \\
\hline & Levenberg-Mlarquardt & $\begin{array}{lll}4 & 30 & 1 \\
\end{array}$ & 6,488 & 9,6 & 7,315 & 0,962 & 7,142 & 0,953 \\
\hline & & $\begin{array}{lll}4401 \\
\end{array}$ & 9,848 & 0,992 & 17,62 & 0,9 & 5,82 & 0,955 \\
\hline & & $4 \quad 101$ & 5,264 & 0,959 & 5,261 & 0,956 & 5,264 & 0,959 \\
\hline & Bayesian & 4201 & 5,469 & 0,953 & 4,427 & 0,967 & 5,313 & 0,959 \\
\hline Friday & Regularization & 43301 & 5,618 & 0,957 & 3,88 & 0,967 & 5,535 & 0,958 \\
\hline & & 4401 & 4,973 & 0,957 & 7,792 & 0,959 & 5,40 & 0,958 \\
\hline & & $\begin{array}{lll}4 & 10 & 1 \\
\end{array}$ & 7,8 & 0,939 & 10,75 & 0,916 & 8,242 & 0,936 \\
\hline & Scaled Conjugate & $\begin{array}{lll}420 & 1 \\
\end{array}$ & 7,21 & 0,939 & 8,64 & 0,935 & 7,075 & 0,944 \\
\hline & Gradient & 4301 & 5,193 & 0,96 & 8,97 & 0,944 & 6,528 & 0,950 \\
\hline & & $\begin{array}{lll}4 & 40 & 1 \\
\end{array}$ & 3,723 & 0,97 & 6,4 & 0,958 & 4,767 & 0,963 \\
\hline & & $\begin{array}{lll}4 & 10 & 1 \\
\end{array}$ & 6,715 & 0,956 & 8,992 & 0,945 & 8,62 & 0,947 \\
\hline & Jeyenhero-Marguardt & 4201 & 3,334 & 0,98 & 5,21 & 0,963 & 4,86 & 0,970 \\
\hline & Levenberg-Marquardt & 4301 & 2,072 & 0,987 & 12,99 & 0,945 & 6,159 & 0,966 \\
\hline & & 4401 & 4,883 & 0,997 & 10,24 & 0,943 & 6,459 & 0,962 \\
\hline & & $4 \quad 101$ & 8,959 & 0,944 & 18,38 & 0,934 & 10,372 & 9,359 \\
\hline & Bayesian & 4201 & 10,53 & 0,936 & 4,9 & 0,967 & 9,69 & 0,939 \\
\hline Saturday & Regularization & $4 \quad 301$ & 10,558 & 0,928 & 5,9 & 0,979 & 9,86 & 0,938 \\
\hline & & $\begin{array}{lll}4401 \\
\end{array}$ & 4,13 & 0,973 & 20,17 & 0,9 & 6,538 & 0,959 \\
\hline & & $\begin{array}{lll}4 & 10 & 1 \\
\end{array}$ & 8,32 & 0,946 & 13,838 & 0,936 & 9,296 & 0,942 \\
\hline & Scaled Conjugate & 4201 & 9,522 & 0,941 & 14,386 & 0,948 & 10,374 & 0,934 \\
\hline & Gradient & 4301 & 6,213 & 0,959 & 11,91 & 0,968 & 8,477 & 0,948 \\
\hline & & $\begin{array}{lll}4 & 40 & 1 \\
\end{array}$ & 7,785 & 0,973 & 11,712 & 0,92 & 9,095 & 0,943 \\
\hline
\end{tabular}


Table 3 Table titles Comparative ANN learning algorithm and network structure results (continuation)

\begin{tabular}{|c|c|c|c|c|c|c|c|c|}
\hline \multirow{2}{*}{ Day } & \multirow{2}{*}{ Training Algorithm } & \multirow{2}{*}{$\begin{array}{l}\text { Network } \\
\text { Structure }\end{array}$} & \multicolumn{2}{|c|}{ Training } & \multicolumn{2}{|c|}{ Testing } & \multicolumn{2}{|c|}{ Validating } \\
\hline & & & $M S E$ & $R$ & $M S E$ & $R$ & $M S E$ & $R$ \\
\hline \multirow{12}{*}{ Sunday } & \multirow{4}{*}{ Levenberg-Marquardt } & 4101 & 5,417 & 0,963 & 9,308 & 0,93 & 5,954 & 0,960 \\
\hline & & 4201 & 3,123 & 0,982 & 14,142 & 0,964 & 7,02 & 0,960 \\
\hline & & $\begin{array}{lll}4 & 30 & 1\end{array}$ & 2,059 & 0,985 & 8,113 & 0,938 & 3,404 & 0,977 \\
\hline & & $\begin{array}{lll}4 & 40 & 1\end{array}$ & 0,0029 & 0,9999 & 49,86 & 0,881 & 12,54 & 0,933 \\
\hline & \multirow{4}{*}{$\begin{array}{c}\text { Bayesian } \\
\text { Regularization }\end{array}$} & $4 \quad 101$ & 4,824 & 0,967 & 9,086 & 0,951 & 5,446 & 0,964 \\
\hline & & 4201 & 4,511 & 0,971 & 4,287 & 0,963 & 4,478 & 0,970 \\
\hline & & 4301 & 4,76 & 0,968 & 5,117 & 0,966 & 4,811 & 0,968 \\
\hline & & 4401 & 5,034 & 0,965 & 9,236 & 0,962 & 5,647 & 0,963 \\
\hline & \multirow{4}{*}{$\begin{array}{l}\text { Scaled Conjugate } \\
\text { Gradient }\end{array}$} & 4101 & 9,738 & 0,935 & 12,755 & 0,92 & 9,744 & 0,935 \\
\hline & & 4201 & 8,22 & 0,95 & 8,54 & 0,93 & 7,573 & 0,949 \\
\hline & & 4301 & 5,417 & 0,963 & 8,779 & 0,956 & 5,84 & 0,961 \\
\hline & & $\begin{array}{lll}4 & 40 & 1\end{array}$ & 6,993 & 0,953 & 8,216 & 0,946 & 9,993 & 0,933 \\
\hline
\end{tabular}

Considering the ANN tests with different schemes, BR algorithm seems to yield better results for all days with an average training $R$ of 0.957 and testing $R$ of 0.954 among the others. Later, LM and SCG algorithms produced the highest scores, respectively. Generally, the fastest training algorithm was the LM surpassing the others, however, it produced unacceptable results and lower accuracy mostly for the data used. Additionally, BR algorithm gave the similar accuracy and prediction values during all trials, showing a stable run.

When the ANN structures have been analysed, 4-20-1 and 4-30-1 forms mostly produced highest scores with a desired accuracy. So, for our problem hidden layer neuron count may fall in 20-30. The ANN form of 4-10-1 was mostly unsuccessful either in training or testing stages. The 4-40-1 form mostly produced over predicted or under predicted data, indicating memorizing the dataset. This unsuccessful form of ANN produced high training scores, however, testing scores were lower than the others. Ultimately, in order to fine tuning the hidden layer neuron counts of ANN of BR optimization, a second training campaign was conducted by changing the hidden layer neuron count from 20 to 30 , increasing by 2 neurons at every step, considering the results given in Tab. 3. Tab. 4 shows the results from this last training for determining the optimum hidden layer neuron count.

Table 4 Comparative ANN learning algorithm and network structure results

\begin{tabular}{|c|c|c|c|c|c|c|c|c|}
\hline \multirow[b]{2}{*}{ Day } & \multirow{2}{*}{$\begin{array}{c}\text { Training } \\
\text { Algorithm }\end{array}$} & \multirow{2}{*}{ Network Structure } & \multicolumn{2}{|c|}{ Training } & \multicolumn{2}{|c|}{ Testing } & \multicolumn{2}{|c|}{ Validating } \\
\hline & & & $M S E$ & $R$ & $M S E$ & $R$ & $M S E$ & $R$ \\
\hline \multirow{4}{*}{ Monday } & \multirow{4}{*}{$\begin{array}{c}\text { Bayesian } \\
\text { Regularization }\end{array}$} & $\begin{array}{lll}4 & 22 & 1\end{array}$ & 9,956 & 0,922 & 4,298 & 0,970 & 9,131 & 0,928 \\
\hline & & $4 \begin{array}{lll}4 & 24 & 1\end{array}$ & 9,772 & 0,917 & 4,254 & 0,976 & 8,967 & 0,929 \\
\hline & & $\begin{array}{llll}4 & 26 & 1\end{array}$ & 9,921 & 0,9219 & 4,994 & 0,971 & 9,202 & 0,928 \\
\hline & & $\begin{array}{llll}4 & 28 & 1\end{array}$ & 9,5178 & 0,93 & 5,7282 & 0,899 & 8,965 & 0,929 \\
\hline \multirow{4}{*}{ Tuesday } & \multirow{4}{*}{$\begin{array}{c}\text { Bayesian } \\
\text { Regularization }\end{array}$} & $\begin{array}{lll}4 & 22 & 1 \\
\end{array}$ & 4,8243 & 0,9684 & 6,4225 & 0,9657 & 5,0574 & 0,968 \\
\hline & & $\begin{array}{llll}4 & 24 & 1 \\
\end{array}$ & 5,5981 & 0,9648 & 5,2604 & 0,9779 & 5,5489 & 0,965 \\
\hline & & $\begin{array}{lll}4 & 26 & 1\end{array}$ & 5,6009 & 0,96678 & 5,17493 & 0,95709 & 5,53878 & 0,962 \\
\hline & & $\begin{array}{llll}4 & 28 & 1 \\
\end{array}$ & 4,7857 & 0,9691 & 3,15002 & $\begin{array}{l}0,98379 \\
\end{array}$ & 4,5472 & 0,972 \\
\hline \multirow{4}{*}{ Wednesday } & \multirow{4}{*}{$\begin{array}{c}\text { Bayesian } \\
\text { Regularization }\end{array}$} & $\begin{array}{lll}4 & 22 & 1\end{array}$ & 8,5865 & 0,9392 & 4,6997 & 0,95982 & 8,0196 & 0,941 \\
\hline & & $\begin{array}{llll}4 & 24 & 1\end{array}$ & 8,5107 & 0,93714 & 5,4699 & 0,93691 & 8,0672 & 0,941 \\
\hline & & $\begin{array}{llll}4 & 26 & 1 \\
\end{array}$ & 8,66575 & 0,93786 & 4,80897 & 0,97235 & 8,10331 & 0,941 \\
\hline & & $\begin{array}{lll}4 & 28 & 1 \\
\end{array}$ & 8,88221 & 0,93775 & 4,10901 & 0,9561 & 8,18612 & 0,940 \\
\hline \multirow{4}{*}{ Thursday } & \multirow{4}{*}{$\begin{array}{l}\text { Levenberg- } \\
\text { Marquardt }\end{array}$} & $\begin{array}{llll}4 & 22 & 1 \\
\end{array}$ & 10,4775 & 0,95069 & 6,33 & 0,96676 & 11,687 & 0,938 \\
\hline & & $\begin{array}{llll}4 & 24 & 1\end{array}$ & 1,23341 & 0,99323 & 2,88047 & 0,98992 & 4,51896 & 0,974 \\
\hline & & $\begin{array}{llll}4 & 26 & 1 \\
\end{array}$ & 2,9672 & 0,98172 & 5,66847 & 0,96488 & 3,77147 & 0,976 \\
\hline & & $\begin{array}{lll}4 & 28 & 1\end{array}$ & 7,9663 & 0,95758 & 5,49259 & 0,97399 & 9,16705 & 0,949 \\
\hline \multirow{4}{*}{ Friday } & \multirow{4}{*}{$\begin{array}{c}\text { Bayesian } \\
\text { Regularization }\end{array}$} & $\begin{array}{llll}4 & 22 & 1\end{array}$ & 4,6126 & 0,96272 & 4,18973 & 0,97318 & 4,5491 & 0,965 \\
\hline & & $\begin{array}{lll}4241 \\
\end{array}$ & 4,61234 & 0,96426 & 4,09063 & 0,96696 & 4,53408 & 0,965 \\
\hline & & $\begin{array}{lll}4 & 26 & 1 \\
\end{array}$ & 5,6292 & 0,95546 & 2,76619 & 0,98365 & 5,19979 & 0,960 \\
\hline & & $\begin{array}{lll}4 & 28 & 1\end{array}$ & 5,5495 & 0,955232 & 3,81522 & 0,97659 & 5,28942 & 0,959 \\
\hline \multirow{4}{*}{ Saturday } & \multirow{4}{*}{$\begin{array}{c}\text { Bayesian } \\
\text { Regularization }\end{array}$} & $\begin{array}{lll}422 & 1 \\
\end{array}$ & 10,5661 & 0,93362 & 4,9319 & 0,96977 & 9,721 & 0,939 \\
\hline & & $\begin{array}{lll}4 & 24 & 1 \\
\end{array}$ & 10,7373 & 0,92988 & 4,45089 & 0,97234 & 9,79435 & 0,939 \\
\hline & & $\begin{array}{lll}42 & 261 \\
\end{array}$ & 105956 & 0,9304 & 5,12746 & 0,97553 & 9,77538 & 0,939 \\
\hline & & $\begin{array}{lll}4 & 28 & 1\end{array}$ & 10,6222 & 0,93347 & 5,23211 & 0,96412 & 9,81375 & 0,938 \\
\hline \multirow{4}{*}{ Sunday } & \multirow{4}{*}{$\begin{array}{c}\text { Bayesian } \\
\text { Regularization }\end{array}$} & $\begin{array}{lll}4 & 22 & 1 \\
\end{array}$ & 9,1011 & 0,93984 & 4,74724 & 0,96721 & 8,64761 & 0,942 \\
\hline & & $\begin{array}{llll}4 & 24 & 1\end{array}$ & 5,31395 & 0,966228 & 4,43154 & 0,96439 & 5,19107 & 0,966 \\
\hline & & $4 \begin{array}{lll}4 & 26 & 1\end{array}$ & 4,90415 & 0,96707 & 4,44641 & 0,975641 & 4,85647 & 0,968 \\
\hline & & $\begin{array}{lll}428 & 1 \\
\end{array}$ & 6,68906 & 0,956707 & 4,7665 & 0,96706 & 6,38463 & 0,958 \\
\hline
\end{tabular}

The values given in Tab. 4 were compared with predicted values obtained by ANN and the validity of the method was examined, comparing to $M S E$ and $R$ performance criteria. Here, the best training and testing score can be compared using Pearson's moment correlation coefficients as the minimum and the maximum training and testing $R$ values of $(0.917$ and 0.933$)$ and $(0.899$ and
0.990). These values showed that training was successfully done by ANN models in general which is supported by testing $R$ scores. Among the model scores given in Tab. 4, the Bayesian Regulation based ANN models outperformed. The performance scores obtained by fine tuning the ANNs are given in Tab. 5. 
Table 5 The best ANN structures with optimization algorithms for days of April

\begin{tabular}{|c|l|c|c|c|c|}
\hline \multicolumn{2}{|c|}{ Table 5 The best ANN structures with optimization algorithms for days of April } \\
\hline Day & Training Algorithm & Network Structure & $M S E$ & \multicolumn{2}{c|}{$R$} \\
\hline Monday & Bayesian Regularization & $4-24-1$ & 4.254 & 0.970 \\
\hline Tuesday & Bayesian Regularization & $4-28-1$ & 3.150 & 0.941 \\
\hline Wednesday & Bayesian Regularization & $4-30-1$ & 2.474 & 0.984 \\
\hline Thursday & Levenberg-Marquardt & $4-24-1$ & 2.880 & 0.989 \\
\hline Friday & Bayesian Regularization & $4-26-1$ & 2.766 & 0.989 \\
\hline Saturday & Bayesian Regularization & $4-24-1$ & 4.451 & 0.984 \\
\hline Sunday & Bayesian Regularization & $4-20-1$ & 4.287 & 0.978 \\
\hline
\end{tabular}

According to MSE values, it was showed that the values were lower than 4.5 with an average $M S E$ of 3.466 and $R^{2}$ of 0.958 . Here, $R^{2}$ values were ranged in 0.927 (Saturday) and 0.978 (Wednesday and Thursday). Considering the mean error statistics and accuracy scores, for this specific problem to predict electricity load ANN models yield reasonably successful prediction results with the help of similar-day based modeling scheme. In order to compare actual values with the ANN predictions for each day in the dataset, line plots in Fig. 5 were given for the days of the last week of April. Here, all line plots indicated that hourly-historical pattern was followed very-well by ANN models, except some points at peaks and valleys. However, ANN models run no over-predictions or underpredictions in general.
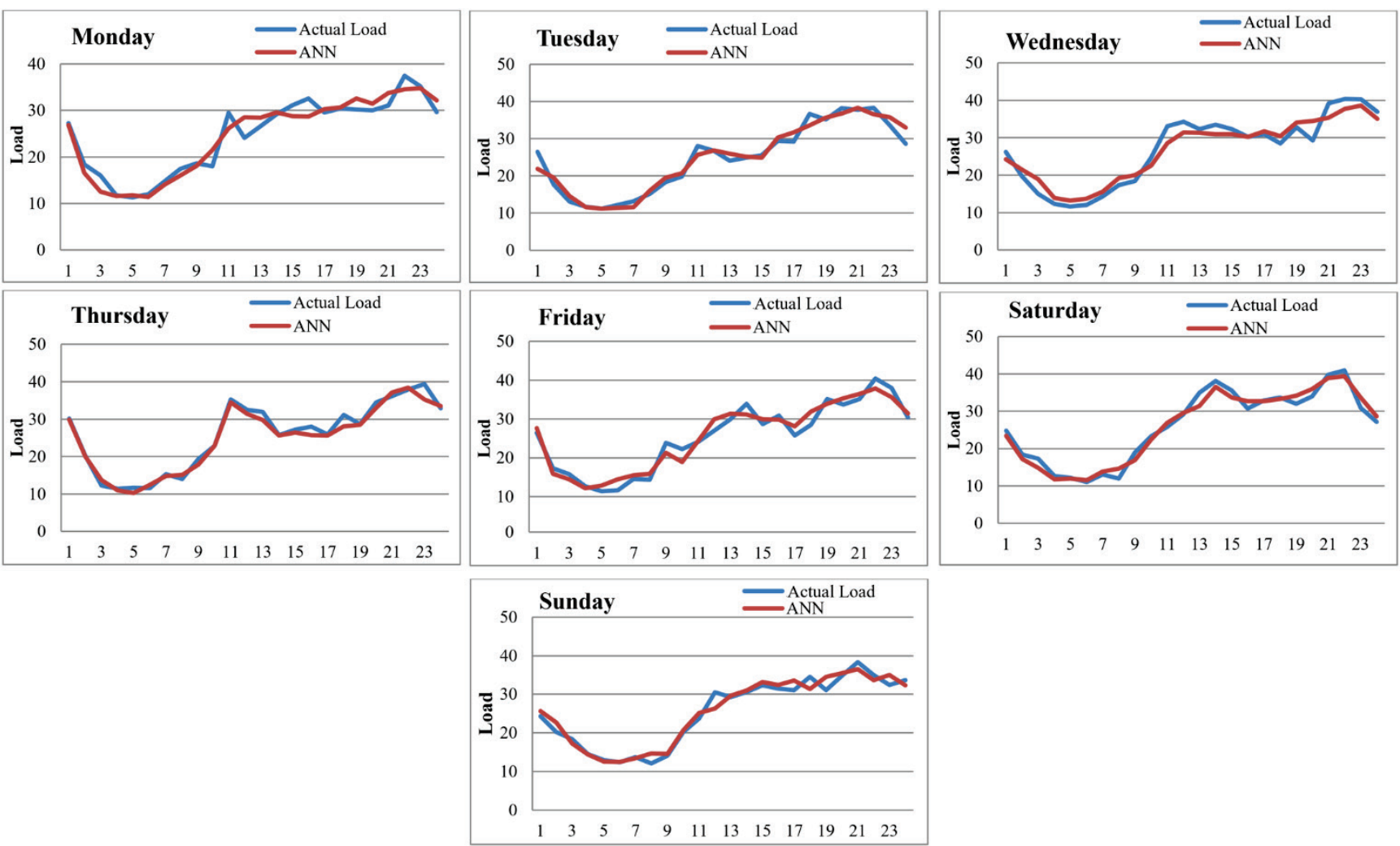

Figure 5 Comparison of daily ANN prediction results from the last week of April

This shows that ANN's generalization ability is good enough for our problem and predictions are statistically acceptable. In order to increase success rate of selected ANN models, it is evidently revealed that data amount in training phase should be increased, which is technically linked to the number of remote meter equipment. However, we know that hourly or half-hourly reading of electricity load is very limited due to increasing cost in the world such as in England with a number of 2000-2500 subscribers [33].

\section{CONCLUSIONS}

In this study, the estimation of electricity consumption was modelled with ANNs, taking historical hourly data pattern of air temperature, electricity consumption and actual hour information into account. Accurate estimates of the electricity consumption enable us to accurately determine the load profiles used in the calculation of the electricity energy imbalance costs, emphasizing reducing the imbalance costs. The errors that are predicted by the required electricity cause the imbalance costs to increase. More accurate estimation methods are needed to reduce the imbalance costs. Sakarya Electricity Distribution Company in Turkey (SEDAŞ) residential consumption varies depending on the information provided by the hourly temperature measurements used. ANN model was applied for load estimations. With load profiles determined, load estimates were made for different day types such as Monday, Tuesday, and Wednesday, and the differences between them were compared, depending on the probability that the hourly temperature values would 
change. When the load estimates obtained according to the temperature are examined, it has been understood that the load profiles can be obtained more correctly with the ANN model if the temperature and time information are taken into account. Accurate estimations will contribute to reducing unbalanced flows, and there is a great deal of importance in making consumption plans more reliable. By using the ANN Model, which is proposed as an alternative estimation method in this study, it is demonstrated that short term electricity consumption estimations can be done reliably by using meteorological forecasting information. Even if used ANN models produced acceptable and statistically significant predictions, genetic algorithm optimized hybrid models or some models with extra meteorological inputs might be studied to advance modelling framework.

\section{Acknowledgements}

This study was carried out in cooperation with SEDAŞ and Düzce University within the scope of "Influence of Optimization Method on Uncertainty Costs of Profile Coefficients Methodology and Optimization Project" supported by EPDK on May 28.

\section{REFERENCES}

[1] Song, K. B., Baek, Y. S., Hong, D. H., \& Jang, G. (2005). Short-term load forecasting for the holidays using fuzzy linear regression method. IEEE transactions on power systems, 20(1), 96-101. https://doi.org/10.1109/TPWRS.2004.835632

[2] Chen, H., Canizares, C. A., \& Singh, A. (2001). ANN-based short-term load forecasting in electricity markets. In Power Engineering Society Winter Meeting, IEEE, Vol. 2, 411-415.

[3] Holjevac, N., Soares, C., \& Kuzle, I. (2017). Short-term power system hourly load forecasting using artificial neural networks. Energija, 66(1-4), 0-0.

[4] Azadeh, A., Ghadrei, S. F., \& Nokhandan, B. P. (2009, March). One day-ahead price forecasting for electricity market of Iran using combined time series and neural network model. In Hybrid Intelligent Models and Applications, HIMA'09, IEEE Workshop on, 44-47. https://doi.org/10.1109/HIMA.2009.4937824

[5] Campbell, P. R. \& Adamson, K. (2006, September). Methodologies for load forecasting. In Intelligent Systems, $20063^{\text {rd }}$ International IEEE Conference on, 800-806. https://doi.org/10.1109/is.2006.348523

[6] Chow, J. H., Wu, F. F., \& Momoh, J. A. (2005). Applied mathematics for restructured electric power systems. In Applied Mathematics for Restructured Electric Power Systems, Springer, Boston, MA, 1-9. https://doi.org/10.1007/0-387-23471-3_1

[7] Engle, R. F., Mustafa, C., \& Rice, J. (1992). Modelling peak electricity demand. Journal of forecasting, 11(3), 241-251. https://doi.org/10.1002/for.3980110306

[8] Yang, H. T., Huang, C. M., \& Huang, C. L. (1996). Identification of ARMAX model for short term load forecasting: an evolutionary programming approach. IEEE Transactions on Power Systems, 11(1), 403-408. https://doi.org/10.1109/59.486125

[9] Bakirtzis, A. G., Petridis, V., Kiartzis, S. J., Alexiadis, M. C., \& Maissis, A. H. (1996). A neural network short term load forecasting model for the Greek power system. IEEE Transactions on power systems, 11(2), 858-863. https://doi.org/10.1109/59.496166
[10] Ertugrul, Ö. F. (2016). Forecasting electricity load by a novel recurrent extreme learning machines approach. International Journal of Electrical Power \& Energy Systems, 78, 429-435. https://doi.org/10.1016/j.jiepes.2015.12.006

[11] Park, D. C., El-Sharkawi, M. A., Marks, R. J., Atlas, L. E., \& Damborg, M. J. (1991). Electric load forecasting using an artificial neural network. IEEE transactions on Power Systems, 6(2), 442-449. https://doi.org/10.1109/59.76685

[12] Szkuta, B. R., Sanabria, L. A., \& Dillon, T. S. (1999). Electricity price short-term forecasting using artificial neural networks. IEEE transactions on power systems, 14(3), 851857. https://doi.org/10.1109/59.780895

[13] Lee, K. Y., Cha, Y. T., \& Park, J. H. (1992). Short-term load forecasting using an artificial neural network. IEEE Transactions on Power Systems, 7(1), 124-132. https://doi.org/10.1109/59.141695

[14] Taylor, J. W., \& Buizza, R. (2002). Neural network load forecasting with weather ensemble predictions. IEEE Transactions on Power Systems, 17(3), 626-632. https://doi.org/10.1109/TPWRS.2002.800906

[15] Yao, R. \& Steemers, K. (2005). A method of formulating energy load profile for domestic buildings in the UK. Energy and Buildings, 37(6), 663-671. https://doi.org/10.1016/j.enbuild.2004.09.007

[16] Morch, A. Z., Feilberg, N., Sæle, H., \& Lindberg, K. B. (2013). Method for development and segmentation of load profiles for different final customers and appliances. ECEEE Summer Study Proceedings, Belambra Les Criques, France, 1e6 June, 1927e1933.

[17] Songpu, A., Kolhe, M. L., Jiao, L., \& Zhang, Q. (2015, May). Domestic load forecasting using neural network and its use for missing data analysis. In Advanced Topics in Electrical Engineering (ATEE), $9^{\text {th }}$ International Symposium on, IEEE, 535-538. https://doi.org/10.1109/ATEE.2015.7133866

[18] Rahman, S. \& Bhatnagar, R. (1988). An expert system based algorithm for short term load forecast. IEEE Transactions on Power Systems, 3(2), 392-399. https://doi.org/10.1109/59.192889

[19] Felea, I., Dan, F., \& Dzitac, S. (2012). Consumers Load Profile Classification Corelated to the Electric Energy Forecast. Proceedings of the Romanian Academy, Series A, 13(1), 80-88.

[20] Frank, S. M., \& Sen, P. K. (2011, August). Estimation of electricity consumption in commercial buildings. In North American Power Symposium (NAPS), IEEE, 1-7. https://doi.org/10.1109/NAPS.2011.6024898

[21] Fausett, L. (1994). Fundamentals of neural networks: architectures, algorithms, and applications. Prentice-Hall, Inc.

[22] Trippi, R. R. \& Turban, E. (1992). Neural networks in finance and investing: Using artificial intelligence to improve real world performance. McGraw-Hill, Inc.

[23] Öztemel, E. (2003). Yapay Sinir Ağlari. Papatya Yayincilik, Istanbul.

[24] Yegnanarayana, B. (2009). Artificial neural networks. PHI Learning Pvt. Ltd.

[25] Kaynar, O. \& Taştan, S. (2009). Zaman Serisi Analizinde MLP Yapay Sinir Ağları ve Arima Modelinin Karşılaştırılması, Erciyes Üniversitesi İktisadi ve İdari Bilimler Fakültesi Dergisi, (33), 161-172.

[26] Gene, H. J. T. \& Ding, A. A. (1997). Prediction intervals for artificial neural networks. Journal of the American Statistical Association, 92(438), 748-757. https://doi.org/10.1080/01621459.1997.10474027

[27] Vemuri, V. R. (1994). Artificial neural networks (Concepts and control applications. Institute of Electrical and Electronic Engineers (IEEE) Computer Society Press. Los Alamitos, California. https://doi.org/10.1016/S0065-2458(08)60272-7 
[28] Elmas, C. (2003). Yapay Sinir Ağları (Theory, Architecturue, Education, Application). Seckin Yayıncilik, Ankara.

[29] Çavuşlu, M. A., Becerikli, Y., \& Karakuzu, C. (2012). Levenberg-Marquardt Algoritmas1 ile YSA Eğitiminin Donanımsal Gerçeklenmesi (Hardware Implementation of Neural Network Training with Levenberg-Marquardt Algorithm). Türkiye Bilişim Vakfi Bilgisayar Bilimleri ve Müh. Dergisi, 5

[30] Eren, B., Yaqub, M., \& Eyüpoğlu, V. (2016). Polimer içerikli membran verimi tahmininde yapay sinir ağları öğrenme algoritmalarının değerlendirilmesi. Sakarya Üniversitesi Fen Bilimleri Enstitüsü Dergisi, 20(3), 533-542.

[31] Jayalakshmi, T. \& Santhakumaran, A. (2011). Statistical normalization and back propagation for classification. International Journal of Computer Theory and Engineering, 3(1), 89. https://doi.org/10.7763/IJCTE.2011.V3.288

[32] Fuxiang, G., Wenxin, X., \& Langtao, L. (2010, July). Overview on remote meter reading system based on GPRS. In Industrial and Information Systems (IIS), $20102^{\text {nd }}$ International Conference on, IEEE, Vol. 2, 270-273.

[33] See https://www.elexon.co.uk/wp-content/uploads/2013/11/ load_profiles_v2.0_cgi.pdf

\section{Contac information:}

Assoc. Prof. Dr. Salih TOSUN

Duzce University,

Faculty of Technology,

Dept. Electrical - Electronics Engineering,

Konuralp Yerleskesi,

81620 Duzce / Turkey

salihtosun@duzce.edu.tr

\section{Ali ÖZTÜRK}

Duzce University,

Faculty of Technology,

Dept. Electrical - Electronics Engineering,

Konuralp Yerleskesi,

81620 Duzce / Turkey

\section{Assoc. Prof. Dr. Fatih TAŞPINAR}

Duzce University,

Faculty of Technology,

Dept. Electrical - Electronics Engineering,

Konuralp Yerleskesi,

81620 Duzce / Turkey 